THE RETURNS TO EDUCATION AND TRAINING:

\author{
EVIDENCE FROM THE MALAYSIAN FAMILY LIFE SURVEYS
}

\author{
Tsung-Ping Chung
}

July 2000

\begin{abstract}
The main purpose of this paper is to investigate the private returns to education and training for a random sample of women in Malaysia in the 1980s. We estimate a standard Mincerian earnings function, augmented by information on the women's training experience. The results indicate that there are positive and economically significant returns to education and training. We also investigate the determinants of training and find that training participation is positively related to educational attainment, while if women are credit-constrained, they are significantly less likely to undertake training. We also examine the issue of self-selection in training participation and find that self-selection does not appear to cause an upward bias to the estimated returns to training for our sample.
\end{abstract}

JEL Classification: J24, J31

Keywords: Education, Training, Wage Determination, Self-selection, Malaysia

Acknowledgements: I am indebted to Professor Francis Green and Dr. Andy Dickerson for their valuable comments and advice. I am also grateful for comments received from participants at my PhD upgrading seminar in March 2000.

Address for Correspondence: Tsung-Ping Chung, Department of Economics, Keynes College, University of Kent at Canterbury, Canterbury, KENT CT2 7NP, UK. Tel: +44 1227 823168; Fax: +44 1227 827850; email: tpc2@ukc.ac.uk 


\section{THE RETURNS TO EDUCATION AND TRAINING: \\ EVIDENCE FROM THE MALAYSIAN FAMILY LIFE SURVEYS}

\section{Introduction}

The available information relating to education and training in Malaysia is currently rather limited. This paper seeks to expand our knowledge in two ways. We first present estimates of the returns to education and the gross returns to training $\square_{\text {for a random sample of Malaysian }}$ women in the 1980s. We then investigate the determinants of training and explore the issue of self-selection in training participation.

The existing studies relating to education and training in Malaysia are reviewed in section 2. Our modelling approach is an augmented Mincerian earnings function and this is briefly outlined in section 3 together with a detailed description of the data which are taken from the two Malaysian Family Life Surveys (MFLS). The results on the returns to education and training are presented in section 4 . We find that there are high and significant returns to both education and training for women in Malaysia in the 1980s. Section 5 investigates the determinants of training provision and examines the extent of the bias in the returns to training resulting from self-selection into training participation. The bias is found to be small and statistically insignificant. Section 6 presents our conclusions.

\footnotetext{
${ }^{1}$ The term gross returns to training is used since we have no information on the costs of training provision.
} 


\section{Previous Studies on Education and Training in Malaysia}

Most previous studies on education and training in Malaysia have utilised the standard human capital model and its empirical implementation - a Mincerian earnings function - to evaluate the rate of return to education.

The first and most comprehensive estimates of the private and social rate of returns to education in Malaysia were obtained by Hoerr (1973) using the 1967-68 Socio-Economic Sample Survey of households. Among the five levels of schooling examined, the highest private rate of return was to upper secondary schooling at 18.9 percent and the lowest was for degree holders at 11.4 percent. On the basis of his results, Hoerr suggested two implications for public policy consideration. First, given that social returns to secondary education were unstable, he recommended a diminution in the rate of expansion in secondary education. At the same time, as private returns to secondary education were high, Hoerr suggested that there should be a redistribution of resources toward the educationally underprivileged. Secondly, the social return to university education was poor and he expected it to deteriorate further in the ensuing years in the face of rapid expanding enrolment. He suggested that selective expansion could be continued (more towards science orientated courses) and any general expansion of enrolment should be permitted only with the framework of constant total cost.

Mazumdar (1981) used two different datasets in her study. The first was the 1970 Post Enumeration Survey (PES) which had information on 8,095 urban male employees and the self-employed. The second dataset was the World Bank Migration and Employment Survey (MES) for 1975 which covered 1,889 male employees in three urban centres in Malaysia (Kuala Lumpur, Kuantan and Kota Bahru). While the MES was geographically constrained to the three cities, it was a more comprehensive survey than the PES as it contained additional 
information such as background variables and type of employer.

Using the PES data, Mazumdar found evidence of particularly high returns to education from completed educational phases after the primary level, although the returns to additional years of schooling were not constant. Moreover, she found that the increase in earnings for those who dropped out between completion of one phase and the next was small. She interpreted this as evidence supporting the screening hypothesis, implying that employers attach more importance to workers' possession of a certificate of completion of a given phase of education than to the number of years of schooling per se.

Using the more comprehensive MES, Mazumdar (1981) applied the simple human capital model separately for the public and private sector. Two salient results were drawn from this analysis. Firstly, the proportion of variance explained is twice as high for the public sector (0.67) compared to the private sector (0.31). This underlines the importance of education and age variables in a public sector wage determination system that emphasises formal schooling and seniority. Secondly, education played a relatively large part in the explanation of earnings ${ }^{\text {[ }}$. One caveat, as Lee (1980) notes, is that Mazumdar's data covered only recent school leavers aged 19 to 22 years.

Lee (1980) obtained rate of returns estimates from a non-random sample of 1,179 private sector employees and 792 public sector employees in the Klang Valley. Education ranks as one of the most important variables in the explanation of earnings differentials and this is

2 The education dummies alone explained 57 percent of the variance for the public sector employees while the addition of the age and age-squared added only another 10 percent to the $\mathrm{R}^{2}$. For the private sector, the corresponding percentages were 24 percent and 8 percent. 
interpreted as evidence in favour of a human capital explanation for the correlation between education and earnings. Given the low marginal rate of returns to lower secondary schooling, Lee raised some concern over the continued expansion of education at this level. In relation to the effectiveness of education as a policy variable for the reduction of inter-racial inequalities, Lee's results indicated that almost half of the inter-racial earnings differential in the private sector may be attributable to discrimination which, on the whole, favours the Chinese over the Malays and the Indians. In the public sector, inter-racial differentials are largely attributable to inter-racial differences in earnings characteristics, in particular education. Lee's results showed that, while there was no strong evidence in support of a rigid segmentation of the labour market, there were significant inter-racial differences in the impact of education on occupational status and occupational mobility, as well as in the openness of occupational structures which, in general, tended to favour the Chinese.

Lee et al (1995) summarised results from two surveys of particular industrial workers conducted in 1989 and 1992. The first comprised 2,553 employees taken from ten industries $\frac{\text { Z }}{\text {, }}$ and was further confined to six key occupations within these industries (electrical and electronic equipment assemblers; electrical fitters; machinery fitters; metal formers; supervisors and engineering assistants). The second survey contained data on 1,445 employees in eight industries ${ }^{\boxplus}$ within the manufacturing sector located in the Kuala Lumpur urban labour market. Lee et al (1995) presented estimates for rates of return for males and females separately in these selected manufacturing sectors. Unlike previous studies found

${ }^{3}$ These were: electronics \& electrical; textile and apparel; machinery and engineering; wood based; rubber products; food processing; chemical products; transport equipment and services; mining and construction.

${ }^{4}$ These were: electronics \& electrical; textile and apparel; machinery and engineering; wood based; rubber products; food processing; chemical products; fabricated metal products. 
elsewhere, these show rates of returns for men to be higher than those for women.

In a more recent study using a Malaysian household data set, Ruppert (1998) found the rate of returns to education to be only 2 percent. However, as only household data were available, the earnings used in her model were not at the individual level. In addition, due to the nature of her study, Ruppert's model included controls on occupation, which would bias the results by removing cross-occupation mobility effects (Sapsford and Tzannatos, 1993).

There has been a number of studies investigating the returns to training. A report submitted to the ILO and the Government of Malaysia in 1989 (cited in Lee et al, 1995) found that returns to certificate level training from private institutions tended to be higher than training from government institutions. This provided support to the government's policy of encouraging the development of private training institutions. However, this study did not cover other training types such as on-the-job training provided by both public and private firms.

Wan Abdul (1995) gathered qualitative data on training provision for 60 randomly selected manufacturing firms in 1993. He found that transnational corporations (TNCs) have a greater incidence of training and re-training their work force. This training is found to have been provided to production workers, skilled workers and management staff. TNCs were also found to be more successful in retaining trained workers through re-training programmes, better pay schemes, promotions and prospects for career advancement. Wan Abdul also found that the general level of technical and industrial skills in Malaysia were relatively low even though there was evidence of increased training and skill acquisition among the firms interviewed. Moreover, firms reported an acute shortage of both skilled and unskilled workers. 
In a more comprehensive and comparative study, Tan and Batra (1995) echoed some of the findings in Wan Abdul's study. They used a probit model to analyse training provision among 2,200 Malaysia firms. Small firms (up to 100 workers) were more likely to conduct internal training programmes than external training programmes, and, as compared to medium (101250 workers) and large firms (more than 250 workers), small firms tended to undertake less training. Small firms were also more likely to only train skilled workers as compared to the more widespread training programmes of both medium and large firms. Firms with a more highly educated or highly skilled workforce had a greater likelihood of conducting formal training. Firms with a higher percentage of automation were found to be likely to conduct external training programmes. Firms practising quality control measures were also likely to train.

Tan and Batra (1995) found that the impact of trades unions on training provision in Malaysia was positive. This effect was stronger on external training compared to in-house training and also larger for skilled worker training. Firms with higher investments in R\&D had a significantly higher likelihood of enterprise training. Foreign owned firms were also more likely to conduct training both internally and externally. In contrast to the results for the other four countries in their study (Taiwan, Mexico, Colombia and Indonesia), export-orientated firms in Malaysia were no more likely to provide enterprise training. Overall, the incidence of training provision in Malaysia was found to be relatively high; Malaysia was ranked first in terms of the provision of informal training, and second for the provision of formal training.

Tan and Batra also examined the effects of training on firm-level productivity using an augmented Cobb-Douglas production function. A simple training indicator dummy for the 
provision of any training was positive but insignificant, but became statistically significant once a suitable correction was made for selectivity bias in training provision. Disaggregating by skill and type of training provision revealed that it was only internal formal training for skilled workers that had a significant positive effect on firm-level productivity. Further analysis of the source of training revealed that Government training for both unskilled and skilled workers actually had a negative (although statistically insignificant) effect on firmlevel productivity, while internal training and external training for skilled workers provided by industry associations had positive and statistically significant effects on productivity.

While this review indicates that there is a reasonable amount of literature on the rate of returns to education in Malaysia, we find that amongst the limited number of studies on training, none investigate the benefits or impact of training for the individual. There are also no studies which can identify who is more likely to receive or participate in training at the individual level. This paper rectifies both of these weaknesses.

\section{Model and Data}

\subsection{Modelling Framework}

For our analysis of the returns to education and training, we estimate a standard Mincerian earnings function augmented by a measure of training:

$$
\ln Y_{i}=\beta^{\prime} \mathbf{X}_{i}+\gamma_{1} a g e_{i}+\gamma_{2} a g e_{i}^{2}+\delta T_{i}+\varepsilon_{i}
$$

where $Y_{i}$ is earnings, $\mathbf{X}_{i}$ is a vector of variables deemed to have an influence on earnings, including schooling and $T_{i}$ is a $0 / 1$ dummy variable reflecting the incidence of training.

The determinants of training experience are also investigated using a conventional probit 
model:

$$
T_{i}^{*}=\mu^{\prime} \mathbf{Z}_{i}
$$

where $T_{i}^{*}$ is a latent variable measuring the value of training, such that if $T^{*}>0, T=1$ while if $T^{*} \leq 0$, then $T=0 . \mathbf{Z}_{i}$ is a vector of the determinants of training.

\subsection{Data Description}

The data used in this study are derived from the first two Malaysian Family Life Surveys (MFLS) conducted in 1976 and 1988. The surveys were only conducted in Peninsular Malaysia which includes around 80 to 85 percent of the total Malaysian population. The main objective of the surveys was to investigate key economic and biomedical relationships affecting birthspacing, family size and breastfeeding patterns of families in Peninsular Malaysia. However, the data collected are so rich that they have also enabled investigations of migration, education, labour markets, income distribution etc. to be undertaken (see, inter alia, DaVanzo and Kusnic, 1983; De Tray, 1984, 1985, 1988; Blau, 1985; Rosenweig and Schultz, 1987; Lillard and Willis, 1994; Pong, 1996, 1997).

MFLS1 was conducted in 1976-1977. Fieldwork was administered in three rounds, with each round being separated by a four-month interval. The main respondents were randomly selected ever-married women (EMW) under the age of 50. Additional respondents included the spouses belonging to the EMWs. Appendix Table A1 provides details of the coverage of the 11 questionnaires administered in the different rounds. The second MFLS was conducted in 1988. A number of new samples were introduced, and extra information was collected on certain issues such as training. Appendix Table A2 provides details of the questionnaire coverage of MFLS2. As the MFLS are retrospective surveys, one may have doubts about the data quality. However, Sine (1991) assessed the MFLS2 data and found that the 
“... data is of very high quality. It performs well on tests of internal consistency and it is at least as good, and sometimes better, than other data it was compared to".

We can identify four separate samples in MFLS2:

1. Panel Sample - contains data from the re-interviewed women from MFLS1. A follow-up rate of 70 percent was achieved (i.e. 889 out of the 1,262 women interviewed in 1976 were re-interviewed). The husband belonging to the woman interviewed was also reinterviewed.

2. Children Sample - contains data for grown children (aged 18 or over) belonging to the women in the Panel Sample. Up to three children were randomly selected - one from those living at home with his/her mother and two children living elsewhere.

3. New Sample - consists of randomly selected women (i.e regardless of marital status) aged 18 to 49 years old. If the women were married, their husbands were also interviewed.

4. Senior Sample - a sample of households with a person aged 50 or older.

The information provided by the women in the first two samples was combined and will henceforth be known as the Panel and Children Sample while the information provided by the women in the third sample is referred to as the New Sample in the results below.

The strength of the MFLS for this study lies in the information on training. Data on training have only been collected by individuals or the government on an ad-hoc basis. Although Malaysia does have a Labour Force Survey (LFS) which is conducted annually and is combined once in every two years with the Household Income Survey, the information collected is confined to labour market issues such as unemployment and underemployment while the household income survey covers other aspects of living, e.g. migration, utilities, transportation, education but there are no specific questions pertaining to training. 
In MFLS1, the following questions pertaining to training were asked:

Since your $15^{\text {th }}$ birthday have you attended any job-related training programmes or courses? By that, I mean any special study either at your place of work or elsewhere to help you with your job or occupation. (INCLUDE ON-THE-JOB TRAINING).

Prompt: Please include any periods of job-training you had while you also were attending school/college/university or any period of training or apprenticeship while you were working

If yes, the respondent was then asked:

a) In what year did you begin your (first, second, etc.) training programme? In what month? How old were you then?

b) In what year did that (first, second, etc.) training programme end? In what month? What was your age then?

c) Did you attend that training programme full time? If no, how many hours a week did you attend?

d) Did you attend any other job-related training programme after that?"

In MFLS2, the questions relating to training were as follows:

Have you ever attended any job-related training programmes or courses? By that, I mean any special study either at a school, a shop, your place of work or elsewhere to help you with your job or occupation.

(PROBE): Please include any periods of job training you had while you also were attending school/college/university or any period of training or apprenticeship while you were working.

If yes:

a) How many job-related training programmes have you taken part in?

I'd like to ask you about (each of your/IF MORE THAN TWO: your two longest) training programmes. Let's start with the longest one first.

FOR EACH PROGRAMME

b) What type of training was that? (Probe: Was it at school or provided by your employer?)

c) When did you begin that programme? (How old were you then?)

d) How long did that programme last?

e) Did you attend the programme full time or part-time?

f) If part time: How many hours a week did you attend?

g) Who paid for your job related training?

The earnings variable used in this study is net earnings, including in-kind payments such as 
housing or meals and clothing. One problem with defining earnings is that the survey reveals that 29 percent of Panel and Children sample and 24 percent of the New Sample respondents were multiple job holders. Thus, in the income data file, a given individual may have several income earning activities listed. While combining all records would be ideal, we would then be unable to identify the occupation of the respondent. Hence only earnings from the first income producing activity (which in terms of hours worked was the main work that the individual was doing) are taken. These are then divided by the hours worked in that particular activity to produce a measure of wages.

The education levels have been banded into five categories:

\begin{tabular}{|l|l|l|}
\hline Variable & Education Level & Highest Certificate Received \\
\hline PRIM & Completed Primary Schooling & None \\
\hline LOWSEC & Completed Lower Secondary Schooling & SRP (Lower Certificate of Education) \\
\hline UPPSEC & Completed Upper Secondary Schooling & $\begin{array}{l}\text { SPM (Malaysia Certificate of Education) or } \\
\text { SPVM (Malaysia Cert. of Vocational Ed.) }\end{array}$ \\
\hline PREUNI & Completed Pre-University & $\begin{array}{l}\text { STPM (Higher School Certificate) or } \\
\text { a Diploma or certificate from college }\end{array}$ \\
\hline HIGHED & Completed Higher Education & $\begin{array}{l}\text { Bachelors, Masters or PhD or other } \\
\text { doctorates }\end{array}$ \\
\hline
\end{tabular}

Training was defined to the interviewers as a job-related training course held either at the place of work or elsewhere that lasted for at least one week. Examples of training listed in the interviewer's instruction manual were apprenticeships and vocational training, pre-service training which included military training, etc and other pre-service training which lasted for less than 2 years, in-service training such as management and supervisory training and other training courses that a person attended while working. The TRAIN variable is a dummy variable created based on the respondent's answer to "How many job-related training programmes have you taken part in?" (NTRAIN). 
We also disaggregate training provision according to its provider (private or government or other) and into full-time or part-time. Tables 1A, 1B and 1C provide full details and summary statistics for the variables used.

\section{4. $\quad$ Results}

The results for the Panel and Children Sample are presented in Table 2. Column (1) shows the results for the regression containing only age and the education variables. Column (2) includes marital status while the results in column (3) include the training variable. The employment status of the woman is included in column (4). Column (5) details the results of the regression which includes the race variables.

The signs of the coefficients are as expected. In column (1), positive and significant returns are obtained for all educational levels. The highest return is for those with higher education qualifications. Only 2 percent of the women in the sample had reached this level which may explain why such high returns are found ${ }^{6}$. Marital status appears to be unimportant for earnings. Column (3) reveals that the training dummy is positive and highly significant and

\footnotetext{
${ }^{5}$ The return to higher education - i.e. university degree level - was also found to be very high in the study by Mazumdar (1981) using the Migration and Emigration Survey of 1975. She estimated returns to a degree of 202 percent for principle male earners working in the public sector and 180 percent for those working in the private sector. An important issue pertaining to the estimates of the rate of returns to education is that because of the endogeneity of the education level attained, the rate of return will be overestimated. However, in recent research, there appears to be some consensus that the bias is small. In addition, even where there are large differences between the OLS results and those obtained after controlling for bias, the differences are insignificant (see Dearden, 1999 and Griliches, 1997). Based on these findings, we have some confidence that our OLS estimates of the returns to education are reasonably reliable.
} 
indicates a $39^{6}$ percent increase in earnings if the woman had participated in a job-related training programme. Employers and unpaid ${ }^{\square}$ workers receive lower wages compared to the control group (employees). Ceteris paribus, a Chinese woman earns an average of 32 percent more than Malays (the reference category) while a woman of Indian/Others race earns 17 percent more (although this latter impact is not statistically significant).

The marginal rate of return ${ }^{\mathrm{B}}$ to successive levels of education, PRIM to LOWSEC, LOWSEC to UPPSEC, UPPSEC to PREUNI and PREUNI to HIGHED are 12 percent, 17 percent, 26 percent and 17 percent respectively using the results in column (5).

Table 3 examines the impact of the first longest training the woman has ever attended. The results in column (1) show that both private and government type training bring positive and significant returns. Moreover, the returns are very similar. Full-time training participants appear to benefit more than those which undertake part-time training as seen in column (2). Finally, column (3) reveals that those who trained 30 or more years ago appeared to have the highest returns to their training. One possible explanation could be the comparative scarcity of trained woman 30 years ago (in the 1950s) and the elevated status they achieved. This variable could also be capturing additional returns to experience that trained women received.

The results for the New Sample are shown in Table 4. The rate of returns to education are

${ }^{6}$ The calculation of the percentage effect of a dummy variable in a semilogarithmic equation is given by: $100 \times[\exp (\beta)-1]$ (Halvoren and Palmquist, 1980).

${ }^{7}$ These (family) workers receive only income in-kind.

${ }^{8}$ The marginal rate of return for different levels of schooling $S 1$ and $S 2$ is calculated as (Psacharoupoulos, 1981 and Mazumdar, 1980): $r_{(S 2 v s S 1)}=100 \times\left[\exp \left(\frac{\beta_{2}-\beta_{1}}{S 2-S 1}\right)-1\right]$ where $\mathrm{Sj}$ is the number of years of schooling (SPRIM=6, SlowSEC=9, SuPPSEC=11, SPREUNI=13 and SHIGHED=17). 
positive and significant, and, as in the Panel and Children Sample, the women with higher education qualifications receive the greatest returns. Moreover, the magnitudes of the returns are similar. Marital status is associated with a significant differential of around 22 percent, unlike in the Panel and Children Sample of mainly EMW.

Participation in a job-related training programme also has a positive impact on income for the women in the New Sample. As can be seen in column (3), hourly income increases by 27 percent for those who have ever participated in a job-related training programme. The results in column (4) show that, as compared to employees, unpaid family workers get 24 percent higher wages, and employers 25 percent lower wages. When the race variable is included into the regression, as in column (5), there are small increases in the magnitude of the education coefficients as compared to column (4), and both the Chinese and Indian/Others race variables are positive and significant. Finally, the training variable remains positive and significant when the race variables are included, indicating a 22 percent increase in earnings for those having participated in a training programme.

The marginal rate of returns for the New Sample are 8 percent for LOWSEC vs PRIM, 22 percent for UPPSEC vs LOWSEC, 23 percent for PREUNI vs UPPSEC and 13 percent for HIGHED vs PREUNI using the results in column (5).

Table 5 shows the results of the analysis for the first longest training the New Sample respondent had participated in. Those who have participated in private training programme for their first longest training enjoy an increase in earnings of 44 percent compared to a 12 percent increase for those who had participated in a government training programme (although the latter is statistically insignificant). When the training types are disaggregated 
according to their full- or part-time basis, private training is seen to have a positive and significant impact on income regardless of its status, although the return to full-time private training is almost double that of part-time private training. There are increasing returns to how long ago the training took place, similar to the finding for the Panel and Children Sample, and again, this could be picking up the experience and cohort effects of such training.

\section{The Determinants of Training and Self-Selection Bias}

It is possible that the women who have undergone training are not randomly selected but rather have been chosen according to ability and/or educational qualifications. As a result, the estimated returns to training programmes presented in the previous section could potentially be biased upwards/downwards if above/below-average ability workers choose (or are selected) to undertake training programmes. Thus in this section we apply the treatment effects model of selectivity (Greene, 1997, section 20.4.4 and Maddala, 1985, section 9.2) to correct for any (self-)selection bias using the standard Heckman two-stage procedure. This involves first estimating a training participation equation, i.e. equation (2) above. In the second stage, these estimates are used to calculate the Inverse Mills Ratio (IMR), $\lambda$, which is included as an additional regressor in the earnings equation to obtain selection bias-corrected parameter estimates. This analysis can only be carried out on the Panel Sample since we require information from MLFS1 which can then be used to correct for any selection bias in the estimated returns to training estimated from MFLS2.

The first stage in the analysis requires the specification of the determinants of training function, including the identifying restriction (i.e. a variable that determines the training participation decision but does not influence earnings). We use whether a woman had savings 
in the bank (BANK) as the identifying variable, the hypothesis being that such an individual is more likely to participate in training (possibly self-paid). Other than BANK, the probability of training participation in 1988 is hypothesised to be related to the woman's marital status, the level of education achieved in 1976, and her parents' occupational status.

Table 6 presents the results of the probit regressions used to analyse the determinants of training ${ }^{1}$. Column (1) includes the woman's marital status in 1976, her highest education level achieved in 1976 and the BANK variable. Columns (2) and (3) include her mother's working status and, additionally, father's occupation respectively while column (4) includes the race variables.

Column (1) indicates that marital status does not appear to be a significant factor in the probability of a woman being trained. However, the higher the education level, the higher the probability that the woman will receive training and the results for this variable are highly significant. Having savings in a bank also increases the probability that the woman will participate in some sort of job related training. This indicates that money saved could be invested in education and training and also provides evidence that credit constraints may be a factor influencing training participation.

Columns (2) and (3) reveal that the probability of a woman being trained is lower if her mother is not working, and significantly lower if her father is in the agriculture sector. The latter can be perhaps be explained by examining the culture within the agricultural sector in Malaysia, both historically and today. Agriculture is a sector in which the work is traditionally

\footnotetext{
${ }^{9}$ Of the 889 women from MFLS1 re-interviewed in MFLS2, we have complete data on 525 respondents.
} 
passed down from father to son. Hence, the probability of a daughter being trained to take over her father's agricultural land or work will be lower compared to the propensity of her brother or husband being trained.

Column (4) reveals that the Chinese appear to have a significantly higher probability of participating in training compared to the Malays. The coefficient on the BANK variable remains positive although it is insignificant when the race variables are included, perhaps reflecting the correlation between these variables.

Table 7 presents the results from the second stage of the analysis, namely the selectioncorrected earnings function. We use the Table 6 regressions including parental occupational status to calculate the IMR. In columns (1) and (2), the results are reported with and without the IMR, and excluding the race variables. Columns (3) and (4) are similar, but are extended to include the race variables. All educational level coefficients remain positive and significant (with the exception of the lower secondary education level in column (1) which is positive but insignificant). In terms of magnitudes, the coefficients on the education dummies are almost double those obtained in the simple OLS estimates ( $c f$. Table 2, column (3)).

In column (1), when the IMR is not included, the training variable coefficient is 7 percent. When we correct for the potential selection bias by including the IMR, we find that the coefficient on the training variable increases to 14 percent, although the IMR is insignificant. We attribute the insignificance of the training variable to the small sample size as compared to the estimates in Table $2 \frac{10}{}$, and hence it would not be justified to say that there is no selection

\footnotetext{
${ }^{10}$ Only 102 women in the Panel Sample with complete data from MFLS1 also report positive income in MFLS2.
} 
bias. What we can say is that any selection bias does not appear to have biased the OLS estimates for training upwards

Similarly, in columns (3) and (4), when the race variables are included, the training variable coefficient increases from -5 percent to 1 percent. The Chinese race variable is positive and significant while the Indian/Others race variable is negative although insignificant. The Chinese race coefficient is high, and considerably larger than in the simple OLS equation. Thus, our results show that the estimated impact of training is higher after correcting for the potential selection bias.

\section{Summary and Conclusions}

The main objective of this paper is to estimate the returns to education and training using the two MFLS collected in 1976 and 1988. Utilising the standard Mincerian earnings function, we have shown that returns to education are high and positive for the women who participated in the MLFS2 survey. The average rate of return is very high for those with higher education qualifications and the magnitudes obtained are comparable to those obtained by Mazumdar (1981) using 1975 data on principle male earners in the urban areas of Peninsular Malaysia.

The more important and significant finding in this paper is the positive and significant impact of training 2 on earnings for the women in both the Panel and Children Sample and the New Sample (almost 40 percent for the Panel and Children Sample and almost 30 percent for the

\footnotetext{
${ }^{11}$ One possibility not considered here is that our results are also affected by selectivity effects due to the labour force participation decisions by the women in the two surveys.

${ }^{12}$ Some of this positive impact of training might be attributed to unmeasured ability which we cannot control for in our cross-section analysis.
} 
New Sample). This finding ties in with the fact that there was a high demand for trained personnel in Malaysia during its high growth period in the 1980s. Full-time government and private training are found to be more beneficial than the part-time government and private training.

In addition to obtaining the first rough estimates of the gross returns to training in Malaysia, we are also able to identify the determinants of training by using information provided by the Panel Sample in the first MFLS. Those with higher education levels have higher probabilities of participating in training. This confirms that education and training are complements. We also used these estimates to correct for the potential selection bias in the estimated returns to training, and, while statistically insignificant, the returns to training are seen to be larger once we correct for selection. The identifying restriction, namely the availability of savings, indicates that some individuals who are credit constrained may be unable to participate in training even though there are positive returns to training. Previous studies pertaining to the determinants of training in Malaysia and other countries are typically based on firm-level data, and hence cannot identify the determinants of training at the individual level. Thus, for example, the study by the World Bank (1997) showed that one of the reasons that Malaysian firms do not engage in training is due to lack of funds. This paper indicates that the same explanation - lack of funds - could be important at the individual level as well. 


\section{REFERENCES}

Blau, D.M. (1985), "The Effects of Economic Development on Life Cycle Wage Rates and Labour Supply Behaviour in Malaysia”, Journal of Development Economics, Vol. 19, pp. 163-185.

Butz, William, and Julie DaVanzo (1998a), First Malaysian Family Life Survey: 1976 Interviews, Codebook Volume 1: Introduction Through MF6: Income and Wealth, InterUniversity Consortium for Political and Social Research.

Butz, William, and Julie DaVanzo (1998b), First Malaysian Family Life Survey: 1976 Interviews, Codebook Volume 2: Codebook Volume 2: MF7: Female Attitudes and Expectations Through Appendix K, Inter-University Consortium for Political and Social Research.

DaVanzo, Julie and Haaga, J (1999a), Second Malaysian Family Life Survey: 1988 Interviews, Codebook Volume 1: Introduction through MF22: Female Life History, Inter-University Consortium for Political and Social Research.

DaVanzo, Julie and Haaga, J (1999b), Second Malaysian Family Life Survey: 1988 Interviews, Codebook Volume 2: MF23: Male Life history through MF26EB: Community Level Data From MF26, Inter-University Consortium for Political and Social Research.

DaVanzo, Julie and Haaga, J (1999c), Second Malaysian Family Life Survey: 1988 Interviews, User's Guide and Technical Report, Inter-University Consortium for Political and Social Research.

DaVanzo, Julie and Kusnic, M.W. (1983), "Ethnic Differences in Income in Peninsular Malaysia: Their sensitivity to the definition and measurement of income." Singapore Economic Review, Vol. 28-29, pp.22-45.

Dearden, Lorraine (1999), "Qualifications and Earnings in Britain: How Reliable are Conventional OLS Estimates of the Returns to Education?", The Institute of Fiscal Studies Working Paper Series No. W99/7.

De Tray, Dennis (1984), "Schooling in Malaysia: Historical Trends and Recent Enrolments", Paper prepared for the U.S. Agency for International Development.

De Tray, Dennis (1985), "Schooling Policy in Malaysia", Paper prepared for the U.S. Agency for International Development.

De Tray, Dennis (1988), "Government Policy, Household behaviour, and the Distribution of Schooling: A case study of Malaysia”, Research in Population Economics, pp. 303-336.

Greene, William H. (1997), Econometric Analysis, Third Edition, Prentice-Hall International Inc.

Griliches, Zvi (1997), "Education, Human Capital, and Growth: A Personal Perspective", Journal of Labor Economics, Vol. 15(1) pt.2, pp S330-S344.

Halvoren, Robert and Palmquist, Raymond (1980), “The Interpretation of Dummy Variables in Semilogarithmic Equations", The American Economic Review, Vol. 70(3), pp 474475

Hoerr, O.D. (1973), "Education, Income and Equity in Malaysia", Economic Development and Cultural Change, Vol. 21(2), pp.247-273. 
Lee, Kiong Hock (1980), Education, earnings, and occupational status in Malaysia, 1978, Ph.D. thesis, Department of Economics, London School of Economics and Political Science, University of London.

Lee, Kiong Hock, Ng, Sor Tho and Yeoh, Kok Kheng (1995), "Economic Policies, Human Resource Development and Economic Development in Malaysia", University of Malaya (Unpublished).

Lillard, L.A. and Willis, R.J. (1994), "Intergenerational Educational Mobility: Effects of Family and State in Malaysia", The Journal of Human Resources, Vol. XXIX(4), pp. 1126-1166.

Maddala, G.S. (1985), Limited Dependent and Qualitative Variables in Econometrics, Cambridge University Press.

Mazumdar, Dipak (1981), The Urban Labor Market and Income Distribution: A Study of Malaysia, Oxford University Press, Published for the World Bank.

Pong, Suet-Ling (1996), "School Participation of Children from Single Mother Families in Malaysia", Comparative Education Review, Vol. 40(3), pp.231-249.

Pong, Suet-Ling (1997), "Sibship size and Educational Attainment in Peninsular Malaysia: Do Policies Matter?”, Sociological Perspective, Vol. 40(2), pp.227-242.

Rosenzweig, M.R and Schultz, T.P (1987), "Fertility and Investments in Human Capital, Estimates of the Consequences of Imperfect Fertility Control in Malaysia", Journal of Econometrics, Vol. 36, pp.163-184.

Ruppert, Elizabeth (1998), "Managing Foreign Labor in Singapore and Malaysia: Are there Lessons for GCC Countries”, World Bank Working Paper \#2053.

Sapsford, David and Tzannatos, Zafiris (1993), The Economics of the Labour Market, Macmillan Press Ltd.

Sine, Jeffrey (1991), "Data Quality in Retrospective Surveys" in RAND's Proceedings of the Seminar on the Second Malaysian Family Life Survey, Kuala Lumpur, Malaysia, October 1991, edited by Jeffrey Sine, Tey Nai Peng and Julie DaVanzo.

Tan, Hong and Batra, Geetha (1995), "Enterprise Training in Developing Countries: Incidence, Productivity Effects, and Policy Implications", Competitive and Strategy Unit, Private Sector Development Department, The World Bank.

Wan Abdul Wan Aziz (1995), The Human Resource Factor in Malaysia's Economic Growth and Transformation: A Case Study of the Malaysian Manufacturing Firms, PhD Thesis, School of Business and Economic Studies, The University of Leeds.

World Bank (1997), Malaysia: Enterprise Training, Technology, and Productivity, A World Bank Country Study (A joint venture between The World Bank, the United Nations Development Programme and the Government of Malaysia). 
Table 1A: Panel and Children Sample - Descriptive Summary

\begin{tabular}{|c|c|c|c|c|c|}
\hline Variable & $\begin{array}{l}\text { Number } \\
\text { of obs. }\end{array}$ & Mean & $\begin{array}{l}\text { Standard } \\
\text { deviation }\end{array}$ & Minimum & Maximum \\
\hline $\begin{array}{l}\text { Tot. weekly income } \\
\text { (M'sian Ringgit) }\end{array}$ & 686 & 84.423 & 134.964 & 0.729 & 2032.990 \\
\hline LNW & 677 & 0.288 & 0.962 & -4.341 & 3.705 \\
\hline AGE & 926 & 37.105 & 12.893 & 16 & 75 \\
\hline $\mathrm{AGE}^{2}$ & 926 & 1518.046 & 922.756 & 256 & 5625 \\
\hline PRIM & 718 & 0.636 & 0.481 & 0 & 1 \\
\hline LOWSEC & 718 & 0.081 & 0.273 & 0 & 1 \\
\hline UPPSEC & 718 & 0.191 & 0.393 & 0 & 1 \\
\hline PREUNI & 718 & 0.071 & 0.257 & 0 & 1 \\
\hline HIGHED & 718 & 0.021 & 0.143 & 0 & 1 \\
\hline HOURS & 869 & 42.168 & 20.775 & 2 & 168 \\
\hline MARRY & 926 & 0.735 & 0.441 & 0 & 1 \\
\hline TRAIN & 925 & 0.234 & 0.423 & 0 & 1 \\
\hline NTRAIN & 925 & 0.464 & 1.655 & 0 & 30 \\
\hline EMPLOYEE & 926 & 0.508 & 0.500 & 0 & 1 \\
\hline EMPLOYER & 925 & 0.257 & 0.437 & 0 & 1 \\
\hline UNPAID & 925 & 0.235 & 0.424 & 0 & 1 \\
\hline TRAINP & 925 & 0.120 & 0.325 & 0 & 1 \\
\hline TRAING & 925 & 0.042 & 0.201 & 0 & 1 \\
\hline OTHTR & 925 & 0.071 & 0.258 & 0 & 1 \\
\hline FTGTR & 926 & 0.367 & 0.188 & 0 & 1 \\
\hline PTGTR & 926 & 0.054 & 0.073 & 0 & 1 \\
\hline FTPTR & 926 & 0.079 & 0.270 & 0 & 1 \\
\hline PTPTR & 926 & 0.041 & 0.198 & 0 & 1 \\
\hline OTFTTR & 926 & 0.031 & 0.174 & 0 & 1 \\
\hline OTPTR & 926 & 0.040 & 0.196 & 0 & 1 \\
\hline ZERONINE & 926 & 0.119 & 0.324 & 0 & 1 \\
\hline TENMORE & 926 & 0.030 & 0.171 & 0 & 1 \\
\hline TWENMORE & 926 & 0.017 & 0.130 & 0 & 1 \\
\hline THIRTY & 926 & 0.05 & 0.073 & 0 & 1 \\
\hline MALAY & 926 & 0.605 & 0.489 & 0 & 1 \\
\hline CHINESE & 926 & 0.255 & 0.436 & 0 & 1 \\
\hline INDOTH & 926 & 0.140 & 0.348 & 0 & 1 \\
\hline
\end{tabular}


Table 1B: New Sample - Descriptive Summary

\begin{tabular}{|c|c|c|c|c|c|}
\hline Variable & $\begin{array}{l}\text { Number } \\
\text { of obs. }\end{array}$ & Mean & $\begin{array}{l}\text { Standard } \\
\text { deviation }\end{array}$ & Minimum & Maximum \\
\hline $\begin{array}{l}\text { Tot. weekly income } \\
\text { (M'sian Ringgit) }\end{array}$ & 963 & 114.768 & 422.595 & 2.309 & 12487.500 \\
\hline LNW & 954 & 0.549 & 0.834 & -2.495 & 3.754 \\
\hline AGE & 1177 & 32.221 & 7.794 & 17 & 46 \\
\hline $\mathrm{AGE}^{2}$ & 1177 & 1098.880 & 517.236 & 289 & 2401 \\
\hline PRIM & 976 & 0.530 & 0.499 & 0 & 1 \\
\hline LOWSEC & 976 & 0.106 & 0.307 & 0 & 1 \\
\hline UPPSEC & 976 & 0.264 & 0.441 & 0 & 1 \\
\hline PREUNI & 976 & 0.079 & 0.270 & 0 & 1 \\
\hline HIGHED & 976 & 0.022 & 0.145 & 0 & 1 \\
\hline HOURS & 1153 & 43.192 & 18.757 & 1 & 168 \\
\hline MARRY & 1177 & 0.754 & 0.431 & 0 & 1 \\
\hline TRAIN & 1177 & 0.317 & 0.465 & 0 & 1 \\
\hline NTRAIN & 1177 & 0.627 & 1.663 & 0 & 20 \\
\hline EMPLOYEE & 1177 & 0.626 & 0.484 & 0 & 1 \\
\hline EMPLOYER & 1177 & 0.012 & 0.108 & 0 & 1 \\
\hline UNPAID & 1177 & 0.167 & 0.373 & 0 & 1 \\
\hline TRAINP & 1177 & 0.153 & 0.360 & 0 & 1 \\
\hline TRAING & 1177 & 0.064 & 0.244 & 0 & 1 \\
\hline OTHTR & 1177 & 0.100 & 0.300 & 0 & 1 \\
\hline FTGTR & 1177 & 0.057 & 0.232 & 0 & 1 \\
\hline PTGTR & 1177 & 0.007 & 0.082 & 0 & 1 \\
\hline FTPTR & 1177 & 0.110 & 0.314 & 0 & 1 \\
\hline PTPTR & 1177 & 0.042 & 0.202 & 0 & 1 \\
\hline OTFTTR & 1177 & 0.045 & 0.207 & 0 & 1 \\
\hline OTPTR & 1177 & 0.055 & 0.228 & 0 & 1 \\
\hline ZERONINE & 1177 & 0.141 & 0.348 & 0 & 1 \\
\hline TENMORE & 1177 & 0.068 & 0.252 & 0 & 1 \\
\hline TWENMORE & 1177 & 0.014 & 0.119 & 0 & 1 \\
\hline MALAY & 1177 & 0.472 & 0.499 & 0 & 1 \\
\hline CHINESE & 1177 & 0.294 & 0.456 & 0 & 1 \\
\hline INDOTH & 1177 & 0.234 & 0.423 & 0 & 1 \\
\hline
\end{tabular}


Table 1C: MFLS1 data - Descriptive Summary

\begin{tabular}{|l|c|c|c|c|c|}
\hline \multicolumn{1}{|c|}{ Variable } & $\begin{array}{c}\text { Number } \\
\text { of obs. }\end{array}$ & Mean & $\begin{array}{c}\text { Standard } \\
\text { deviation }\end{array}$ & Minimum & Maximum \\
\hline MARST & 843 & 0.947 & 0.225 & 0 & 1 \\
\hline EDUCERT & 525 & 0.202 & 0.692 & 0 & 6 \\
\hline BANK & 843 & 0.272 & 0.445 & 0 & 1 \\
\hline MOTHER & 843 & 0.643 & 0.479 & 0 & 1 \\
\hline F_WHITE & 843 & 0.396 & 0.489 & 0 & 1 \\
\hline F_AGRI & 843 & 0.311 & 0.463 & 0 & 1 \\
\hline F_BLUE & 843 & 0.178 & 0.383 & 0 & 1 \\
\hline F_OTHER & 843 & 0.115 & 0.319 & 0 & 1 \\
\hline MALAY & 843 & 0.546 & 0.498 & 0 & 1 \\
\hline CHINESE & 843 & 0.327 & 0.469 & 0 & 1 \\
\hline INDOTH & 843 & 0.126 & 0.332 & 0 & 1 \\
\hline
\end{tabular}


Table 2: Panel and Children Sample: Human Capital Earnings Function

\begin{tabular}{|c|c|c|c|c|c|}
\hline Variables & (1) & (2) & (3) & (4) & (5) \\
\hline Constant & $\begin{array}{l}-1.685 * * * \\
(0.386)\end{array}$ & $\begin{array}{l}-1.575^{* * * *} \\
(0.420)\end{array}$ & $\begin{array}{l}-1.529 * * * \\
(0.412)\end{array}$ & $\begin{array}{l}-1.486 * * * \\
(0.401)\end{array}$ & $\begin{array}{l}-1.538 * * * \\
(0.399)\end{array}$ \\
\hline $\mathrm{AGE}$ & $\begin{array}{l}0.090 * * * \\
(0.022)\end{array}$ & $\begin{array}{l}0.081 \text { *** } \\
(0.025)\end{array}$ & $\begin{array}{l}0.076^{* * * *} \\
(0.024)\end{array}$ & $\begin{array}{l}0.077 * * * \\
(0.024)\end{array}$ & $\begin{array}{l}0.073 * * * \\
(0.024)\end{array}$ \\
\hline $\mathrm{AGE}^{2}$ & $\begin{array}{l}-0.001 * * * \\
(0.0003)\end{array}$ & $\begin{array}{l}-0.001 * * * \\
(0.0003)\end{array}$ & $\begin{array}{l}-0.001 * * * \\
(0.0003)\end{array}$ & $\begin{array}{l}-0.001 * * * \\
(0.0003)\end{array}$ & $\begin{array}{l}-0.001 * * * \\
(0.0003)\end{array}$ \\
\hline LOWSEC & $\begin{array}{l}0.447 * * * \\
(0.166)\end{array}$ & $\begin{array}{l}0.444 * * * \\
(0.166)\end{array}$ & $\begin{array}{l}0.346^{* *} \\
(0.168)\end{array}$ & $\begin{array}{c}0.311^{*} \\
(0.160)\end{array}$ & $\begin{array}{c}0.352 * * \\
(0.163)\end{array}$ \\
\hline UPPSEC & $\begin{array}{l}0.757 \text { *** } \\
(0.102)\end{array}$ & $\begin{array}{l}0.758^{* * * *} \\
(0.102)\end{array}$ & $\begin{array}{l}0.644 * * * \\
(0.101)\end{array}$ & $\begin{array}{l}0.595^{* * *} \\
(0.098)\end{array}$ & $\begin{array}{l}0.659 * * * \\
(0.106)\end{array}$ \\
\hline PREUNI & $\begin{array}{l}1.328 * * * \\
(0.135)\end{array}$ & $\begin{array}{l}1.326^{* * * *} \\
(0.135)\end{array}$ & $\begin{array}{l}1.155^{* * *} \\
(0.136)\end{array}$ & $\begin{array}{l}1.038^{* * * *} \\
(0.136)\end{array}$ & $\begin{array}{l}1.127 \text { *** } \\
(0.139)\end{array}$ \\
\hline HIGHED & $\begin{array}{l}2.085 \text { *** } \\
(0.183)\end{array}$ & $\begin{array}{l}2.083^{* * * *} \\
(0.180)\end{array}$ & $\begin{array}{l}1.803 \text { *** } \\
(0.212)\end{array}$ & $\begin{array}{l}1.669 * * * \\
(0.210)\end{array}$ & $\begin{array}{l}1.762 * * * \\
(0.207)\end{array}$ \\
\hline MARRY & & $\begin{array}{c}0.059 \\
(0.084)\end{array}$ & $\begin{array}{c}0.036 \\
(0.084)\end{array}$ & $\begin{array}{c}0.066 \\
(0.080)\end{array}$ & $\begin{array}{c}0.079 \\
(0.079)\end{array}$ \\
\hline TRAIN & & & $\begin{array}{l}0.329 * * * \\
(0.089)\end{array}$ & $\begin{array}{l}0.335 * * * \\
(0.087)\end{array}$ & $\begin{array}{l}0.294 * * * \\
(0.087)\end{array}$ \\
\hline EMPLOYER & & & & $\begin{array}{l}-0.337 * * * \\
(0.096)\end{array}$ & $\begin{array}{l}-0.272 * * * \\
(0.103)\end{array}$ \\
\hline UNPAID & & & & $\begin{array}{l}-0.873 \\
(0.604) \\
\end{array}$ & $\begin{array}{l}-0.917 * \\
(0.481) \\
\end{array}$ \\
\hline CHINESE & & & & & $\begin{array}{l}0.275^{* * * *} \\
(0.081)\end{array}$ \\
\hline INDOTH & & & & & $\begin{array}{c}0.153 \\
(0.107)\end{array}$ \\
\hline $\mathrm{R}^{2}$ & 0.29 & 0.29 & 0.30 & 0.32 & 0.33 \\
\hline Sample Size & 534 & 534 & 533 & 533 & 533 \\
\hline
\end{tabular}

Notes:

1. Figures in parenthesis are White heteroskedasticity-corrected standard errors.

2. ***,** and $*$ denotes statistical significance at the 1 percent, 5 percent and 10 percent level respectively. 
Table 3: Panel and Children Sample: First Longest Training

\begin{tabular}{|c|c|c|c|}
\hline Variables & (1) & (2) & (3) \\
\hline Constant & $\begin{array}{l}-1.560 * * * \\
(0.405)\end{array}$ & $\begin{array}{l}-1.531 * * * \\
(0.404)\end{array}$ & $\begin{array}{l}-1.348 * * * \\
(0.416)\end{array}$ \\
\hline AGE & $\begin{array}{l}0.070 * * * \\
(0.024)\end{array}$ & $\begin{array}{l}0.069 * * * \\
(0.024)\end{array}$ & $\begin{array}{l}0.062 * * \\
(0.025)\end{array}$ \\
\hline $\mathrm{AGE}^{2}$ & $\begin{array}{l}-0.001 * * * \\
(0.0003)\end{array}$ & $\begin{array}{l}-0.001 * * * \\
(0.0003)\end{array}$ & $\begin{array}{l}-0.001 * * \\
(0.0003)\end{array}$ \\
\hline LOWSEC & $\begin{array}{c}0.386 * * \\
(0.167)\end{array}$ & $\begin{array}{l}0.389 * * \\
(0.173)\end{array}$ & $\begin{array}{c}0.362 * * \\
(0.168)\end{array}$ \\
\hline UPPSEC & $\begin{array}{l}0.675 * * * \\
(0.103)\end{array}$ & $\begin{array}{l}0.669 * * * \\
(0.105)\end{array}$ & $\begin{array}{l}0.648 * * * \\
(0.101)\end{array}$ \\
\hline PREUNI & $\begin{array}{l}1.155^{* * * *} \\
(0.135)\end{array}$ & $\begin{array}{l}1.080 * * * \\
(0.137)\end{array}$ & $\begin{array}{l}1.179 \text { *** } \\
(0.137)\end{array}$ \\
\hline HIGHED & $\begin{array}{l}1.848^{* * * *} \\
(0.196)\end{array}$ & $\begin{array}{l}1.894 * * * \\
(0.216)\end{array}$ & $\begin{array}{l}1.943 \text { *** } \\
(0.203)\end{array}$ \\
\hline MARRY & $\begin{array}{c}0.068 \\
(0.083)\end{array}$ & $\begin{array}{c}0.067 \\
(0.083)\end{array}$ & $\begin{array}{c}0.058 \\
(0.082)\end{array}$ \\
\hline CHINESE & $\begin{array}{l}0.351 * * * \\
(0.082)\end{array}$ & $\begin{array}{l}0.353 * * * \\
(0.084)\end{array}$ & $\begin{array}{l}0.340 * * * \\
(0.079)\end{array}$ \\
\hline INDOTH & $\begin{array}{l}0.237 * * \\
(0.100)\end{array}$ & $\begin{array}{l}0.257 * * \\
(0.102)\end{array}$ & $\begin{array}{l}0.231 * * \\
(0.100)\end{array}$ \\
\hline Private type training (TRAINP) & $\begin{array}{l}0.403 * * * \\
(0.101)\end{array}$ & & \\
\hline Government type training (TRAING) & $\begin{array}{l}0.323 * * \\
(0.145)\end{array}$ & & \\
\hline Other types of training (OTHTRAIN) & $\begin{array}{l}-0.001 \\
(0.148)\end{array}$ & & \\
\hline Full-time government training programme & & $\begin{array}{l}0.366^{* *} \\
(0.156)\end{array}$ & \\
\hline Part-time government training programme & & $\begin{array}{c}0.007 \\
(0.212) \\
\end{array}$ & \\
\hline Full-time private training programme & & $\begin{array}{l}0.534 * * * \\
(0.125)\end{array}$ & \\
\hline Part-time private training programme & & $\begin{array}{c}0.182 \\
(0.133) \\
\end{array}$ & \\
\hline Full-time in other training programmes & & $\begin{array}{c}0.015 \\
(0.172) \\
\end{array}$ & \\
\hline Part-time in other training programmes & & $\begin{array}{l}-0.059 \\
(0.262) \\
\end{array}$ & \\
\hline $0-9$ years ago & & & $\begin{array}{l}0.193 * * \\
(0.094)\end{array}$ \\
\hline $10-19$ years ago & & & $\begin{array}{l}0.424 * * \\
(0.172)\end{array}$ \\
\hline $20-29$ years ago & & & $\begin{array}{l}0.737 * * \\
(0.307)\end{array}$ \\
\hline 30 and more years ago & & & $\begin{array}{c}0.841^{*} \\
(0.480)\end{array}$ \\
\hline $\mathrm{R}^{2}$ & 0.33 & 0.34 & 0.33 \\
\hline Sample Size & 533 & 534 & 534 \\
\hline
\end{tabular}

Notes:

1. Figures in parenthesis are White heteroskedasticity-corrected standard errors.

2. $* * *, * *$ and $*$ denotes statistical significance at the 1 percent, 5 percent and 10 percent level respectively. 
Table 4: New Sample: Human Capital Earnings Function

\begin{tabular}{|c|c|c|c|c|c|}
\hline Variables & $(1)$ & $(2)$ & (3) & (4) & $(5)$ \\
\hline Constant & $\begin{array}{l}-2.291 * * * \\
(0.377)\end{array}$ & $\begin{array}{l}-1.807 * * * \\
(0.398)\end{array}$ & $\begin{array}{l}-1.560 * * * \\
(0.403)\end{array}$ & $\begin{array}{l}-1.729 * * * \\
(0.391)\end{array}$ & $\begin{array}{l}-1.997 * * * \\
(0.391)\end{array}$ \\
\hline AGE & $\begin{array}{l}0.142^{* * * *} \\
(0.025)\end{array}$ & $\begin{array}{l}0.105^{* * * *} \\
(0.026)\end{array}$ & $\begin{array}{l}0.091 * * * \\
(0.027)\end{array}$ & $\begin{array}{l}0.102^{* * * *} \\
(0.026)\end{array}$ & $\begin{array}{l}0.110^{* * * *} \\
(0.026)\end{array}$ \\
\hline $\mathrm{AGE}^{2}$ & $\begin{array}{l}-0.002 * * * \\
(0.0004)\end{array}$ & $\begin{array}{l}-0.001 * * * \\
(0.0004)\end{array}$ & $\begin{array}{l}-0.001 * * * \\
(0.0004)\end{array}$ & $\begin{array}{l}-0.001 * * * \\
(0.0004)\end{array}$ & $\begin{array}{l}-0.001 * * * \\
(0.0004)\end{array}$ \\
\hline LOWSEC & $\begin{array}{l}0.250 * * * \\
(0.097)\end{array}$ & $\begin{array}{l}0.270 * * * \\
(0.097)\end{array}$ & $\begin{array}{l}0.214 * * \\
(0.100)\end{array}$ & $\begin{array}{l}0.199 * * \\
(0.099)\end{array}$ & $\begin{array}{l}0.239 * * \\
(0.098)\end{array}$ \\
\hline UPPSEC & $\begin{array}{l}0.731 \text { *** } \\
(0.058)\end{array}$ & $\begin{array}{l}0.731 \text { *** } \\
(0.057)\end{array}$ & $\begin{array}{l}0.630 * * * \\
(0.061)\end{array}$ & $\begin{array}{l}0.569 * * * \\
(0.060)\end{array}$ & $\begin{array}{l}0.629 * * * \\
(0.061)\end{array}$ \\
\hline PREUNI & $\begin{array}{l}1.191 \text { *** } \\
(0.079)\end{array}$ & $\begin{array}{l}1.196^{* * * *} \\
(0.080)\end{array}$ & $\begin{array}{l}1.048 \text { *** } \\
(0.091)\end{array}$ & $\begin{array}{l}0.975^{* * *} \\
(0.093)\end{array}$ & $\begin{array}{l}1.044 \text { *** } \\
(0.094)\end{array}$ \\
\hline HIGHED & $\begin{array}{l}1.681 * * * \\
(0.140)\end{array}$ & $\begin{array}{l}1.698 * * * \\
(0.129)\end{array}$ & $\begin{array}{l}1.572 * * * \\
(0.131)\end{array}$ & $\begin{array}{l}1.487 * * * \\
(0.128)\end{array}$ & $\begin{array}{l}1.526 * * * \\
(0.138)\end{array}$ \\
\hline MARRY & & $\begin{array}{l}0.200^{* * * *} \\
(0.062)\end{array}$ & $\begin{array}{l}0.182 * * * \\
(0.061)\end{array}$ & $\begin{array}{l}0.198 * * * \\
(0.060)\end{array}$ & $\begin{array}{l}0.222 * * * \\
(0.059)\end{array}$ \\
\hline TRAIN & & & $\begin{array}{l}0.237 * * * \\
(0.059)\end{array}$ & $\begin{array}{l}0.239 * * * \\
(0.058)\end{array}$ & $\begin{array}{l}0.195 * * * \\
(0.058)\end{array}$ \\
\hline EMPLOYER & & & & $\begin{array}{l}-0.289 * * * \\
(0.077)\end{array}$ & $\begin{array}{l}-0.277 \text { *** } \\
(0.076)\end{array}$ \\
\hline UNPAID & & & & $\begin{array}{l}0.216^{* * * *} \\
(0.060)\end{array}$ & $\begin{array}{l}0.374 * * * \\
(0.071)\end{array}$ \\
\hline CHINESE & & & & & $\begin{array}{l}0.265^{* * * *} \\
(0.061)\end{array}$ \\
\hline INDOTH & & & & & $\begin{array}{l}0.145 * * * \\
(0.053)\end{array}$ \\
\hline $\mathrm{R}^{2}$ & 0.34 & 0.35 & 0.36 & 0.38 & 0.40 \\
\hline Sample Size & 804 & 804 & 804 & 804 & 804 \\
\hline
\end{tabular}

Notes:

1. Figures in parenthesis are White heteroskedasticity-corrected standard errors.

2. ***,** and $*$ denotes statistical significance at the 1 percent, 5 percent and 10 percent level respectively. 
Table 5: New Sample: First Longest Training

\begin{tabular}{|c|c|c|c|}
\hline Variables & (1) & (2) & (3) \\
\hline Constant & $\begin{array}{l}-1.919 * * * \\
(0.394)\end{array}$ & $\begin{array}{l}-1.949 * * * \\
(0.394)\end{array}$ & $\begin{array}{l}-1.948 * * * \\
(0.395)\end{array}$ \\
\hline AGE & $\begin{array}{l}0.103 * * * \\
(0.026)\end{array}$ & $\begin{array}{l}0.105 * * * \\
(0.026)\end{array}$ & $\begin{array}{l}0.107 * * * \\
(0.026)\end{array}$ \\
\hline $\mathrm{AGE}^{2}$ & $\begin{array}{l}-0.001 * * * \\
(0.0004)\end{array}$ & $\begin{array}{l}-0.001 * * * \\
(0.0004)\end{array}$ & $\begin{array}{l}-0.001 * * * \\
(0.0004)\end{array}$ \\
\hline LOWSEC & $\begin{array}{l}0.256^{* * * *} \\
(0.097)\end{array}$ & $\begin{array}{l}0.258 * * * \\
(0.098)\end{array}$ & $\begin{array}{l}0.222 * * \\
(0.098)\end{array}$ \\
\hline UPPSEC & $\begin{array}{l}0.646^{* * *} * \\
(0.063)\end{array}$ & $\begin{array}{l}0.634 * * * \\
(0.065)\end{array}$ & $\begin{array}{l}0.618 * * * \\
(0.064)\end{array}$ \\
\hline PREUNI & $\begin{array}{l}1.039 * * * \\
(0.096)\end{array}$ & $\begin{array}{l}1.000 * * * \\
(0.098)\end{array}$ & $\begin{array}{l}1.022 * * * \\
(0.097)\end{array}$ \\
\hline HIGHED & $\begin{array}{l}1.573 * * * \\
(0.141)\end{array}$ & $\begin{array}{l}1.530 * * * \\
(0.143)\end{array}$ & $\begin{array}{l}1.529 * * * \\
(0.147)\end{array}$ \\
\hline MARRY & $\begin{array}{l}0.222 * * * \\
(0.061)\end{array}$ & $\begin{array}{l}0.215 * * * \\
(0.061)\end{array}$ & $\begin{array}{l}0.196 * * * \\
(0.060)\end{array}$ \\
\hline CHINESE & $\begin{array}{l}0.263 * * * \\
(0.064)\end{array}$ & $\begin{array}{l}0.279 * * * \\
(0.065)\end{array}$ & $\begin{array}{l}0.299 * * * \\
(0.060)\end{array}$ \\
\hline INDOTH & $\begin{array}{l}0.169 * * * \\
(0.055)\end{array}$ & $\begin{array}{l}0.180 * * * \\
(0.055)\end{array}$ & $\begin{array}{l}0.185 * * * \\
(0.054)\end{array}$ \\
\hline Private type training (TRAINP) & $\begin{array}{l}0.363 * * * \\
(0.067)\end{array}$ & & \\
\hline Government type training (TRAING) & $\begin{array}{c}0.114 \\
(0.098) \\
\end{array}$ & & \\
\hline Other types of training (OTHTRAIN) & $\begin{array}{c}0.15 \\
(0.089) \\
\end{array}$ & & \\
\hline Full-time government training programme & & $\begin{array}{c}0.168 \\
(0.106)\end{array}$ & \\
\hline Part-time government training programme & & $\begin{array}{l}-0.178 \\
(0.181)\end{array}$ & \\
\hline Full-time private training programme & & $\begin{array}{l}0.431 * * * \\
(0.068)\end{array}$ & \\
\hline Part-time private training programme & & $\begin{array}{c}0.226^{*} \\
(0.119) \\
\end{array}$ & \\
\hline Full-time in other training programmes & & $\begin{array}{l}-0.005 \\
(0.109)\end{array}$ & \\
\hline Part-time in other training programmes & & $\begin{array}{c}0.033 \\
(0.127) \\
\end{array}$ & \\
\hline $0-9$ years ago & & & $\begin{array}{l}0.266 \text { *** } \\
(0.067)\end{array}$ \\
\hline $10-19$ years ago & & & $\begin{array}{l}0.354 * * * \\
(0.095)\end{array}$ \\
\hline $20-29$ years ago & & & $\begin{array}{l}0.678^{* * *} \\
(0.150)\end{array}$ \\
\hline $\mathrm{R}^{2}$ & 0.39 & 0.40 & 0.39 \\
\hline Sample Size & 804 & 804 & 804 \\
\hline
\end{tabular}

Notes:

1. Figures in parenthesis are White heteroskedasticity-corrected standard errors.

2. $* * *, * *$ and $*$ denotes statistical significance at the 1 percent, 5 percent and 10 percent level respectively. 
Table 6: Panel Sample: Probability of Training Participation

\begin{tabular}{|l|c|c|c|c|}
\hline Variables & $(1)$ & $(2)$ & $(3)$ & $(4)$ \\
\hline Constant & $-1.716^{* * *}$ & $-1.574^{* * *}$ & $-1.458^{* * *}$ & $-1.959^{* * *}$ \\
& $(0.405)$ & $(0.413)$ & $(0.426)$ & $(0.412)$ \\
\hline MARST & 0.460 & 0.513 & 0.512 & 0.411 \\
& $(0.407)$ & $(0.415)$ & $(0.431)$ & $(0.412)$ \\
\hline EDUCERT & $0.698^{* * *}$ & $0.656^{* * *}$ & $0.658^{* * *}$ & $0.784^{* * *}$ \\
& $(0.125)$ & $(0.123)$ & $(0.131)$ & $(0.148)$ \\
\hline BANK & $0.441^{* * *}$ & $0.436^{* *}$ & $0.378^{* *}$ & 0.223 \\
& $(0.141)$ & $(0.143)$ & $(0.148)$ & $(0.162)$ \\
\hline MOTHER & & $-0.338^{* *}$ & -0.091 & -0.050 \\
& & $(0.140)$ & $(0.152)$ & $(0.160)$ \\
\hline F_AGRI & & & $-0.980^{* * *}$ & $-0.709 * * *$ \\
& & & $(0.236)$ & $(0.249)$ \\
\hline F_BLUE & & & -0.126 & -0.205 \\
& & & $(0.182)$ & $(0.194)$ \\
\hline F_OTHER & & & -0.306 & -0.292 \\
& & & $(0.230)$ & $(0.245)$ \\
\hline CHINESE & & & & $1.112^{* * *}$ \\
& & & & $(0.174)$ \\
\hline INDOTH & & & & 0.356 \\
& & & & \\
\hline Sample Size & 525 & 525 & & 525 \\
\hline
\end{tabular}

Notes:

1. Figures in parenthesis are White heteroskedasticity-corrected standard errors.

2. ***, ** and $*$ denotes statistical significance at the 1 percent, 5 percent and 10 percent level respectively. 
Table 7: Panel Sample: Selection Bias Corrected Estimates

\begin{tabular}{|l|c|c|c|c|}
\hline Variables & $(1)$ & $(2)$ & $(3)$ & $(4)$ \\
\hline Constant & -2.690 & -3.325 & -3.271 & -3.742 \\
& $(2.665)$ & $(3.055)$ & $(2.570)$ & $(2.843)$ \\
\hline AGE & 0.133 & 0.150 & 0.154 & 0.163 \\
& $(0.129)$ & $(0.138)$ & $(0.125)$ & $(0.130)$ \\
\hline AGE ${ }^{2}$ & -0.001 & -0.002 & -0.002 & -0.002 \\
& $(0.002)$ & $(0.002)$ & $(0.001)$ & $(0.002)$ \\
\hline LOWSEC & 0.672 & $0.830^{*}$ & $0.670^{*}$ & $0.850^{* *}$ \\
& $(0.431)$ & $(0.445)$ & $(0.413)$ & $(0.408)$ \\
\hline UPPSEC & $1.763^{* * *}$ & $1.957^{* * *}$ & $1.834^{* * *}$ & $2.047 * * *$ \\
& $(0.222)$ & $(0.358)$ & $(0.270)$ & $(0.379)$ \\
\hline PREUNI & $2.450^{* * *}$ & $2.642^{* * *}$ & $2.476^{* * *}$ & $2.650^{* * *}$ \\
& $(0.237)$ & $(0.355)$ & $(0.205)$ & $(0.333)$ \\
\hline HIGHED & $2.642^{* * *}$ & $2.879 * * *$ & $2.890^{* * *}$ & $3.211^{* * *}$ \\
& $(0.228)$ & $(0.404)$ & $(0.301)$ & $(0.486)$ \\
\hline MARRY & $-0.385^{* *}$ & $-0.412^{* *}$ & $-0.332^{* *}$ & $-0.349^{* *}$ \\
& $(0.176)$ & $(0.184)$ & $(0.157)$ & $(0.155)$ \\
\hline TRAIN & 0.071 & 0.131 & -0.047 & 0.009 \\
& $(0.203)$ & $(0.226)$ & $(0.210)$ & $(0.227)$ \\
\hline IMR $(\lambda)$ & & 0.1661 & & 0.149 \\
& & $(0.243)$ & & $(0.221)$ \\
\hline CHINESE & & & $0.347^{* *}$ & $0.413^{* *}$ \\
& & & $(0.149)$ & $(0.184)$ \\
\hline INDOTH & & & -0.133 & -0.274 \\
& & & $(0.336)$ & $(0.319)$ \\
\hline R $^{2}$ & 0.51 & 0.51 & 0.53 & 0.54 \\
\hline Sample Size & 102 & 102 & 102 & 102 \\
\hline
\end{tabular}

Notes:

1. Figures in parenthesis are White heteroskedasticity-corrected standard errors.

2. ***, ** and * denotes statistical significance at the 1 percent, 5 percent and 10 percent level respectively. 
APPENDIX

Table A1: The First Malaysian Family Life Survey (MFLS1)

\begin{tabular}{|c|l|}
\hline Questionnaire Label & \multicolumn{1}{|c|}{ Information collected } \\
\hline MF1 & $\begin{array}{l}\text { Household Roster - this questionnaire records the } \\
\text { demographic characteristics of all persons living in the } \\
\text { household. }\end{array}$ \\
\hline MF2 & $\begin{array}{l}\text { Female Retrospective - elicits information on the EMW's } \\
\text { life history, e.g. education and training, work history, etc. } \\
\text { Information collected covers the time since the } \\
\text { respondent was 15 years old, or age at first marriage or } \\
\text { age at first pregnancy, whichever was earliest. }\end{array}$ \\
\hline MF3 & $\begin{array}{l}\text { Male Retrospective - similar information (with the } \\
\text { exception of questions not relevant to the males, e.g. } \\
\text { pregnancy issues) as collected in the MF2 but this } \\
\text { questionnaire was answered by the EMW's present } \\
\text { husband. }\end{array}$ \\
\hline MF4 and MF5 & $\begin{array}{l}\text { Female and male time budgets, i.e. collecting information } \\
\text { on how time was spent by the EMWs and husbands on } \\
\text { market and non-market activities (e.g. unpaid family } \\
\text { work, child care, schooling, training, etc - excluding } \\
\text { recreational activities and sleep). }\end{array}$ \\
\hline Income and Wealth - This questionnaire gathers all \\
information on all income except that covered in MF4 \\
and MF5.
\end{tabular}

Source: MFLS1 Codebook (Butz and DaVanzo, 1998a; 1998b). 
Table A2: The Second Malaysian Family Life Survey (MFLS2)

\begin{tabular}{|c|l|}
\hline Questionnaire Label & \multicolumn{1}{|c|}{ Information collected } \\
\hline Tracking & $\begin{array}{l}\text { Household tracking - administered to ALL households } \\
\text { where an interview was attempted. }\end{array}$ \\
\hline MF20 & $\begin{array}{l}\text { MFLS1 Roster update - contains current information of } \\
\text { all household members interviewed in MFLS1. }\end{array}$ \\
\hline MF21 & $\begin{array}{l}\text { 1988 Household Roster - all demographic characteristics } \\
\text { of households interviewed in MFLS2. }\end{array}$ \\
\hline MF22 & Female Life history - similar to MF2 in MFLS1. \\
\hline MF23 & Male Life history - similar to MF3 in MFLS1. \\
\hline MF24 & $\begin{array}{l}\text { Senior Life history - used on the Senior Sample } \\
\text { introduced in MFLS2. }\end{array}$ \\
\hline MF25 & $\begin{array}{l}\text { Household Economy - current sources of income, } \\
\text { household possession, ownership and expenses. }\end{array}$ \\
\hline MF26 and MF27 & Community data \\
\hline
\end{tabular}

Source: MFLS2 Codebook, Volume 1 (DaVanzo and Haaga, 1999a; 1999b; 1999c). 